\title{
COMMENTARY
}

\section{Anemia, red blood cell transfusion, and outcomes after severe traumatic brain injury}

\author{
Derek J Roberts ${ }^{1,2,3}$ and David A Zygun ${ }^{* 2,3,4}$ \\ See related research by Sekhon et al., http://ccforum.com/content/16/4/R128
}

\begin{abstract}
In the previous issue of Critical Care, Sekhon and colleagues report that mean 7-day hemoglobin concentration $<90 \mathrm{~g} / \mathrm{l}$ was associated with increased mortality among patients with severe traumatic brain injury (TBI). The adverse relationship between reduced hemoglobin concentrations and outcomes among those with TBI has been an inconsistent finding across available studies. However, as anemia is common among adults with severe TBI, and clinical equipoise may exist between specialists as to when to transfuse allogeneic red blood cells, randomized controlled trials of liberal versus restricted transfusion thresholds are indicated.
\end{abstract}

In the previous issue of Critical Care, Sekhon and colleagues conducted a single-center retrospective cohort study to determine whether hemoglobin concentration was associated with outcomes among 273 critically ill adults with severe traumatic brain injury (TBI) [1]. After adjusting for age, Glasgow Coma Scale scores, external ventricular drain insertion, and allogeneic red blood cell (RBC) transfusion, the authors report that the estimated odds of in-hospital mortality among patients with a mean 7-day hemoglobin concentration $<90$ g/l was 3.1 (95\% confidence interval, 1.5 to 6.3 ) times the estimated odds of in-hospital mortality among those with a mean 7-day hemoglobin concentration $\geq 90 \mathrm{~g} / \mathrm{l}$.

Anemia is common among ICU patients [2]. The etiology of ICU anemia is multifactorial and includes the negative effects of the systemic inflammatory response on hematopoiesis, frequent phlebotomy, and hemodilution from intravenous fluid resuscitation [2]. Among ICU

${ }^{*}$ Correspondence: dzygun@ucalgary.ca

${ }^{3}$ Department of Critical Care Medicine, University of Calgary, Intensive Care Unit Administration, Ground Floor McCaig Tower, Foothills Medical Centre, Room 0446,

3134 Hospital Drive Northwest, Calgary, Alberta, Canada T2N 5A1

Full list of author information is available at the end of the article patients with TBI, the prevalence of reduced hemoglobin concentration ranges from 22 to $69 \%$, depending on the presence or absence of extracranial hemorrhage and the timing of hemoglobin measurements [3].

Although a hemoglobin transfusion threshold $>70 \mathrm{~g} / \mathrm{l}$ was adopted for ICU patients following publication of the Transfusion Requirements in Critical Care trial [4], this target may be poorly tolerated by those with severe TBI [2]. Anemia-induced compensatory mechanisms result in cerebral arteriolar dilatation and increased brain blood flow [2], which could be detrimental for those with cerebral edema or intracranial hypertension. Moreover, as brain tissue oxygen tension is dependent on systemic hemoglobin, reduced hemoglobin concentrations among those with TBI could decrease cerebral oxygen delivery and contribute to brain hypoxia [2].

Although the findings of the study by Sekhon and colleagues provide support for the above physiologic concerns regarding reduced hemoglobin concentrations following brain injury [1], the adverse relationship between anemia and clinical outcomes is an inconsistent finding among available clinical studies [1,5-16]. Of the one randomized controlled trial [10] and the now 14 available cohort studies of which we are aware (two of which were based on post-hoc analyses of similar datasets derived from randomized controlled trials) [1,5-9,11-18], eight reported an association between anemia and an increased risk of poor neurological outcomes or mortality $[1,5,9,11,13,14,17,18]$, while the remaining seven observed no such association. Moreover, in a recent systematic review of comparative studies, insufficient evidence was found to support a difference in outcomes between higher and lower hemoglobin levels among mostly TBI patients [19].

Possible explanations for the inconsistency in results across studies include differences in TBI severity among study patients and inadequate consideration of the effects of anemia during critical time periods [20]. Although a set hemoglobin threshold may exist under which harm may occur among those with TBI, adverse outcomes may be more likely to occur during times of low cerebral blood flow, brain hypoxia, and/or ineffective autoregulation 
$[16,20]$. Some support for this argument was afforded by the findings of a recent retrospective cohort study, which reported that although anemia alone did not appear to be detrimental among patients with severe TBI, the simultaneous combination of anemia and brain hypoxia was linked with an increased risk of unfavorable outcomes [16].

Another significant limitation of the existing literature on this topic has been the absence of a defined diseaseexposure relationship among patients with TBI. Although it is plausible that development of reduced hemoglobin concentrations may be most important during the first 7 days following severe TBI [1], the use of the mean as a summary measure of exposure has the potential to result in exposure misclassification. Moreover, as the effects of anemia on outcomes following TBI are likely to be small, and a tremendous amount of brain hypoxia due to anemia would probably be needed to increase mortality, a sensitive measure of neurological performance or outcome is probably a more important outcome variable [20].

Possibly the most important limitation of the available literature relating anemia to outcomes among those with TBI, however, is the inadequate consideration of the effects of RBC transfusion [19]. Although RBC transfusion often results in a small incremental increase in brain tissue oxygen tension in this patient population, transfused blood has important differences from the patients' own blood and does not always improve cerebral metabolism [2]. Moreover, at least five retrospective cohort studies have reported that RBC transfusion increases the risk of death or worsened neurological outcome among those with TBI $[9,13,14,21,22]$. Admittedly, however, these observations could have been related to selection bias and an unbalanced distribution of outcome determinants between treatment groups [20]. Moreover, as anemia and RBC transfusion are probably highly correlated, those studies that used interaction terms for anemia and RBC transfusion in their regression models probably introduced multicollinearity, and therefore their estimated coefficients and odds ratios may be invalid [20].

In summary, although preclinical experiments suggest several potential adverse effects of anemia among patients with TBI, the results of the available clinical studies are conflicting, and it remains unclear whether $\mathrm{RBC}$ transfusion may further increase risk of adverse outcomes. However, because anemia is common among adults with severe TBI, and a recent survey reported that clinical equipoise may exist among specialists as to when to transfuse allogeneic RBCs [23], randomized controlled trials of liberal versus restricted transfusion thresholds are required among adults with severe TBI. These trials will probably require use of multimodal monitoring to understand whether improved outcomes are only witnessed among those with simultaneous signs of brain hypoxia or cerebral ischemia.

\section{Abbreviations}

$\mathrm{RBC}$, red blood cell; $\mathrm{TBI}$, traumatic brain injury.

\section{Competing interests}

The authors declare that they have no competing interests.

\section{Author details}

'Department of Surgery, University of Calgary, Intensive Care Unit Administration, Ground Floor McCaig Tower, Foothills Medical Centre, Room 0446, 3134 Hospital Drive Northwest, Calgary, Alberta, Canada T2N 5A1. 2Department of Community Health Sciences (Division of Epidemiology), University of Calgary, Intensive Care Unit Administration, Ground Floor McCaig Tower, Foothills Medical Centre, Room 0446, 3134 Hospital Drive Northwest, Calgary, Alberta, Canada T2N 5A1. ${ }^{3}$ Department of Critical Care Medicine, University of Calgary, Intensive Care Unit Administration, Ground Floor McCaig Tower, Foothills Medical Centre, Room 0446, 3134 Hospital Drive Northwest, Calgary, Alberta, Canada T2N 5A1. ${ }^{4}$ Department of Clinical Neurosciences, University of Calgary, Intensive Care Unit Administration, Ground Floor McCaig Tower, Foothills Medical Centre, Room 0446, 3134 Hospital Drive Northwest, Calgary, Alberta, Canada T2N 5 A1

Published: 14 September 2012

\section{References}

1. Sekhon MS, McLean N, Henderson WR, Chittock DR, Griesdale DE: Association of hemoglobin concentration and mortality in critically ill patients with severe traumatic brain injury. Crit Care 2012, 16:R128.

2. Kramer AH, Zygun DA: Anemia and red blood cell transfusion in neurocritical care. Crit Care 2009, 13:R89.

3. Kramer AH, Le Roux P: Red blood cell transfusion and transfusion alternatives in traumatic brain injury. Curr Treat Options Neurol 2012. [Epub ahead of print]

4. Hebert PC, Wells G, Blajchman MA, Marshall J, Martin C, Pagliarello G, Tweeddale M, Schweitzer I, Yetisir E: A multicenter, randomized, controlled clinical trial of transfusion requirements in critical care. Transfusion Requirements in Critical Care Investigators, Canadian Critical Care Trials Group. N Engl J Med 1999, 340:409-417.

5. Miller JD, Sweet RC, Narayan R, Becker DP: Early insults to the injured brain. JAMA 1978, 240:439-442.

6. Miller JD, Butterworth JF, Gudeman SK, Faulkner JE, Choi SC, Selhorst JB, Harbison JW, Lutz HA, Young HF, Becker DP: Further experience in the management of severe head injury. J Neurosurg 1981, 54:289-299.

7. Ariza M, Mataro M, Poca MA, Junque C, Garnacho A, Amoros S, Sahuquillo J: Influence of extraneurological insults on ventricular enlargement and neuropsychological functioning after moderate and severe traumatic brain injury. J Neurotrauma 2004, 21:864-876.

8. Sanchez-Olmedo Jl, Flores-Cordero JM, Rincon-Ferrari MD, Perez-Ale M, Munoz-Sanchez MA, Dominguez-Roldan JM, Murillo-Cabezas F: Brain death after severe traumatic brain injury: the role of systemic secondary brain insults. Transplant Proc 2005, 37:1990-1992.

9. Carlson AP, Schermer CR, Lu SW: Retrospective evaluation of anemia and transfusion in traumatic brain injury. J Trauma 2006, 61:567-571.

10. McIntyre LA, Fergusson DA, Hutchison JS, Pagliarello G, Marshall JC, Yetisir E, Hare GM, Hebert PC: Effect of a liberal versus restrictive transfusion strategy on mortality in patients with moderate to severe head injury. Neurocrit Care 2006, 5:4-9.

11. Van Beek JG, Mushkudiani NA, Steyerberg EW, Butcher I, McHugh GS, Lu J, Marmarou A, Murray GD, Maas Al: Prognostic value of admission laboratory parameters in traumatic brain injury: results from the IMPACT study. J Neurotrauma 2007, 24:315-328.

12. Schirmer-Mikalsen K, Vik A Gisvold SE, Skandsen T, Hynne H, Klepstad P. Severe head injury: control of physiological variables, organ failure and complications in the intensive care unit. Acta Anaesthesio/ Scand 2007, 51:1194-1201

13. Salim A, Hadjizacharia P, DuBose J, Brown C, Inaba K, Chan L, Margulies DR: Role of anemia in traumatic brain injury. J Am Coll Surg 2008, 207:398-406. 
14. Duane TM, Mayglothling J, Grandhi R, Warrier N, Aboutanos MB, Wolfe LG, Malhotra AK, Ivatury RR: The effect of anemia and blood transfusions on mortality in closed head injury patients. J Surg Res 2008, 147:163-167.

15. Yang CJ, Hsiao KY, Su IC, Chen IC: The association between anemia and the mortality of severe traumatic brain injury in emergency department. J Trauma 2011, 71:E132-E135.

16. Oddo M, Levine JM, Kumar M, Iglesias K, Frangos S, Maloney-Wilensky E, Le Roux PD: Anemia and brain oxygen after severe traumatic brain injury. Intensive Care Med 2012, 38:1497-1504.

17. Robertson CS, Gopinath SP, Goodman JC, Contant CF, Valadka AB, Narayan RK: SjvO monitoring in head-injured patients. J Neurotrauma 1995 12:891-896.

18. Steyerberg EW, Mushkudiani N, Perel P, Butcher I, Lu J, McHugh GS, Murray GD, Marmarou A, Roberts I, Habbema JD, Maas Al: Predicting outcome after traumatic brain injury: development and international validation of prognostic scores based on admission characteristics. PLoS Med 2008 5:e165.

19. Desjardins P, Turgeon AF, Tremblay MH, Lauzier F, Zarychanski R, Boutin A, Moore L, Mclntyre LA, English SW, Rigamonti A, Lacroix J, Fergusson DA: Hemoglobin levels and transfusions in neurocritically ill patients: a systematic review of comparative studies. Crit Care 2012, 16:R54.
20. Utter GH, Shahlaie K, Zwienenberg-Lee M, Muizelaar JP: Anemia in the setting of traumatic brain injury: the arguments for and against liberal transfusion. J Neurotrauma 2011, 28:155-165.

21. George ME, Skarda DE, Watts CR, Pham HD, Beilman GJ: Aggressive red blood cell transfusion: no association with improved outcomes for victims of isolated traumatic brain injury. Neurocrit Care 2008, 8:337-343.

22. Warner MA, O'Keeffe T, Bhavsar P, Shringer R, Moore C, Harper C, Madden CJ, Sarode R, Gentilello LM, Diaz-Arrastia R: Transfusions and long-term functional outcomes in traumatic brain injury. J Neurosurg 2010, 113:539-546.

23. Sena MJ, Rivers RM, Muizelaar JP, Battistella FD, Utter GH: Transfusion practices for acute traumatic brain injury: a survey of physicians at US trauma centers. Intensive Care Med 2009, 35:480-488.

doi:10.1186/cc11489

Cite this article as: Roberts DJ, Zygun DA: Anemia, red blood cell transfusion, and outcomes after severe traumatic brain injury. Critical Care 2012, 16:154?? 